\title{
Credibility Perception of Viewers and Brand Equity: A Case Study of Private News Channels in Karachi
}

\author{
Talha Chishti \\ Dr. Mustaghis-ur-Rahman
}

\begin{abstract}
This research studies the key indicators of brand credibility of a selected number of private news channels and aims to reveal the association of brand credibility with the brand equity of these channels. Four private news channels reaching at national level with wide area coverage on cable TV across the country were selected for this study. This is a quantitative study that applies regression analysis to test the formulated hypothesis. The study tests the existence of any association between brand credibility and brand equity of private news channels. Results indicate that fairness and unbiasness of a news channel is a moderate predictor for its high level of brand equity. Furthermore results also indicate that trust in the news channel is a stronger predictor for a high level of brand equity of the channel. The results thus allow the researcher to reject the null hypothesis and accept the alternate hypothesis formulated for this study.
\end{abstract}

Keywords: News channels, brand credibility, brand equity

\section{Introduction}

The emergence of cable TV culture and mushrooming news channels, in the last decade has highlighted the authenticity and credibility issues of the broadcast of these channels. As some private news channels have been accused of promoting "shock culture" and creating unrest in the masses deliberately promoting/broadcasting news that is in bad taste and offensive to the members of the society. These channels are also accused of being biased and favoring a certain group, political party, ideology or just plain commercialism.

This research explores TV audiences' credibility perception of private news channels and their brand equity. The results of this study will help us understand to what extent the audience believes in the reliability and genuineness of the news that is broadcasted by these private news channels. The research will also try to elaborate the relationship of the audiences' brand credibility image of various news channels with the brand equity of those channels.

\subsection{Key Terms and Concepts}

The word Television has been synonymous with news and entertainment since its

Talha Chishti is an MS (MS) Student at SZABIST, Karachi, talhach@gmail.com Dr. Mustaghis-ur-Rahman is an Associate Professor at SZABIST, Karachi, mustaghis@szabist.edu.pk 
commercial availability to the masses in 1941. Since the first broadcast of a television station in Pakistan in 1964, television has steadily become a part of many Pakistani homes and has progressed from black \& white broadcasting to the current digital broadcasting.

Even though some new communication media like mobile phones, Email and the Internet have followed in the recent years, yet the television enjoys the maximum coverage and popularity. Currently, television penetration in Pakistan is more than $47 \%$ households according to Banerjee \& Logan (2008). To create greater understanding of this research, some technical key concepts critical for this research are being discussed below under different headings.

\subsection{Authenticity and Perception}

Webster's (2009) dictionary defines the term "authenticity" as "Worthy of acceptance or belief as conforming to or based on fact." Hachten (2001) says that loss of press credibility is often self inflicted. People rely on news to make daily ordinary or critical decisions. So a news viewer or reader expects that the information being printed or broadcast is authentic and verified.

According to the American Marketing Association (2009), perception is defined as

"Based on prior attitudes, beliefs, needs, stimulus factors, and situational determinants, individuals perceive objects, events, or people in the world about them. Perception is the cognitive impression that is formed of "reality" which in turn influences the individual's actions and behavior toward that object"

Belch \& Belch (2004) are of the view that the product attributes and the perceived outcomes that consumers think that they might experience from the usage of a particular brand are important and they often become the basis on which consumers form attitudes and purchase decisions.

\subsection{Brand Equity and Credibility}

According to the American Marketing Association (2009), Brand Equity is defined as

"The value of a brand. From a consumer perspective, brand equity is based on consumer attitudes about positive brand attributes and favorable consequences of brand use"

The most vital assets of any business are intangible which include the company name, brand, logos, and slogans, their associations, their perceived quality, awareness, customer base, and proprietary resources such as trademarks and patents. These assets, which comprise brand equity, are the primary source of any organization's competitive advantage and future earnings, says David Aaker (1991). He further explains that from a managerial point of view, brand equity encompasses the set of assets - that include brand awareness, brand association, perceived quality and brand loyalty - that 
are attached to a brand.

The strength of any brand is dependant on its familiarity and that it is well regarded (Aaker \& Biel 1993). Meaning, in simpler words, a brand can be considered strong if its credibility with its target audience is high. Research studies have shown (Oyedeji, 2006) a correlation between media credibility and media use and suggest that the higher the levels of media credibility, just like brand equity, the more that media outlet will be preferred by their consumers. Pete Blackshaw (2008) has described six indicators of brand credibility that can adhere to any brand. They are; Trust, Authenticity, Transparency, Affirmation, Listening and Responsiveness

\subsection{Sensationalism and Objectivity in News Reporting}

According to Anderson and Gray (2007) sensationalism is mostly noticed in reporting about violent crimes, glamour or sexually oriented news and disasters. Sensationalism refers not only to the content, but also the style of presentation. Sensational news is not necessarily false, but it is often misleading. News that misleads the public prevents it from accurately determining which course of action to take, which politician to support, which law to support. As Anderson and Gray (2007) has put it, important news can be trivialized and trivial matters given undue attention. Infotainment can lead to a cynical public, one that no longer trusts the accuracy and intentions of press.

The job of the media is to present information. Ideally, personal and political bias is kept out of the presentation of news. In the real world, bias is present in many forms: in language used in the presentation of the story, in the quotes used from interviews, and in background information. According to Streissguth (2006) few people make the claim that unbiased media is a reality.

The idea of objectivity is the defining philosophy of journalism, acknowledging reporters' commitment to disseminating unbiased news and information. (Anderson and Gray, 2007). Trustworthiness, fairness, bias, completeness, respect for privacy, representation of individual interests, accuracy, concern for community well-being, separation of fact and opinion, concern for public interest, factual foundations of information published, and qualifications of reporters are one set of credibility measures as described by Rimmer and Weaver (1987).

\section{Profile of Four Selected Channels for the Study}

We selected four private news channels for this study. Namely GEO News, Express News, ARY Oneworld and Aaj TV. All of these channels enjoy good network coverage and are among the most watched cable news channels in the country.

GEO TV was established in May 2002 as part of the Jang Group of Companies and is the fastest growing TV Channel in Pakistan (GEO TV Website, 2009). According to Media Logic (2009, a media tracking company), GEO News is the most watched news channel on an average in the metropolitan population of Pakistan. 
Express news channel, part of the Lakson Group was launched on January 1st 2008. It is one of the most watched news channels in Pakistan (Express News Website, 2009). Data from Media Logic (2009) says that Express News is the second most watched news channel in the metropolitan population of Pakistan.

ARY One World is a Dubai-based Pakistani news channel launched in 26 September 2004. It is a subsidiary of the larger ARY Digital Network. Media Logic (2009) data says ARY Oneworld is the third most watched news channel among the four selected channels.

AAJ TV is part of the Business Recorder Group and started in March 2005 According to Media Logic (2009), AAJ TV ranks last among the four selected channels being watched.

\section{Methodology and Research Construct}

Input for the study was gathered from the structured questionnaire that was selfadministered or filled through one-on-one interview where required. Its geographic focus was the city of Karachi, specifically targeting the town of North Nazimabad, a well planned town with an upper-middle class population which boasts one of the highest literary rates in the city. Quota sampling has been used to pick the samples from the target population of private news channel viewers. This sampling method was preferred because of the exploratory nature of this study. A total of 112 surveys were completed out which 7 were rejected as they did not fulfill the criteria set for this research. In total 105 surveys were used for data analysis and presentation.

The construct formulated for this study draws on the studies done previously in this field, specifically studies by Aaker (1991), Keller (1993), Yoo and Donthu (2002) and Oyedeji (2006) were referred to construct a Brand Credibility index and subsequently measure the variables. Research done by Mcgrath (1986), Meyer (1988), West (1994) and Oyedeji (2006) were referred to create a Brand Equity index and subsequently measure the variables. The questions in the questionnaire were specifically extracted from these studies to measure the response of the respondents. The validity of these constructs is reinforced by the previous studies conducted in this field and their results.

\section{Data Analysis and Presentation}

The questionnaire was divided into two segments. The first segment gathered personal and demographic information of the respondents and the second segment measured the brand equity and brand credibility indicators. The questionnaire used a 5-point Likert scale to measure the responses. Questions pertaining to brand credibility included; Are you aware of $X$ channel?, I can recognize $X$ channel among other channels on TV, The quality of $X$ reporting is extremely high, The news from $X$ is usable for me, I prefer to watch only $X$ channel over other Urdu news channels, where $X$ denoted the news channel brand.. 
Questions measuring responses on brand equity included; I believe $X$ is fair to all parties involved in a issue in its reporting I believe $X$ is not biased on any issue, I believe $X$ tells the whole story while reporting, I believe news on $X$ is accurate, I can completely trust the news from $X$, where $X$ denoted the news channel brand.

For this study, the variables fairness, biasness, completeness, accuracy and trust are selected as independent variables, in light of the previous study by Oyedeji (2006), which influence the dependent variable that is Brand Equity. To test the critical research question the following hypothesis was developed referring to previous studies Mcgrath (1986), Meyer (1988) and West (1994) which have established the relationship between Brand Credibility and Brand Equity but for products/services other than news media.

H1: Those news channels that have high level of (a) fairness (b) biasness, (c) completeness, (d) trust and (e) accuracy would have no association with the Brand equity of those channels.

H1. At least one of the variables has linear relationship with the dependent variable "Brand Equity of News channels."

Statistical representation of the above hypothesis is presented below:

$H 1_{0}: \quad \beta_{1}=\beta_{2}=\beta_{3}=\beta_{4}=\beta_{5}=0$

$H 1_{A}: \quad \beta_{1} \neq \beta_{2} \neq \beta_{3} \neq \beta_{4} \neq \beta_{5} \neq 0$

The above hypothesis was tested separately for all the four selected channels. While testing the hypothesis and the effects on the dependant variables, (a) brand awareness (b) brand knowledge, (c) perceived quality, (d) usability and (e) loyalty were considered a single variable "Brand Equity" and tested as a single combined variable. The data analysis commences with an examination of the descriptive statistics followed by a regression analysis of the collected data to test the presence of a linear relationship between the independent and dependent variables.

\subsection{Demographic Analysis}

The age of the respondents was spread into 4 categories, that is, 25 to 33,34 to 42 , 43 to 51 and 52 to 60 . Out of 105 respondents 69 respondents (or $66 \%$ ) belonged to the first age group. 26 (or $25 \%$ ) belonged to the second range, 9 (or $9 \%$ ) belonged to the age range of 34 to 42 ; whereas 1 respondent (1\%) belonged to the age range of 52 to 60 .

gure -1

Age Distribution

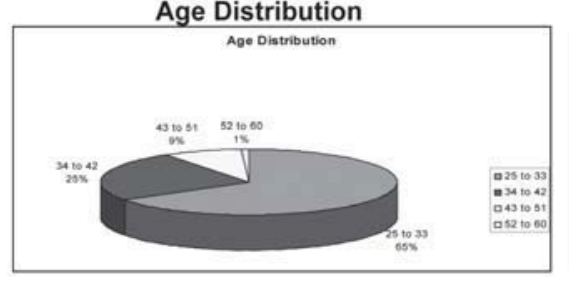

Figure - 2

Gender Distribution

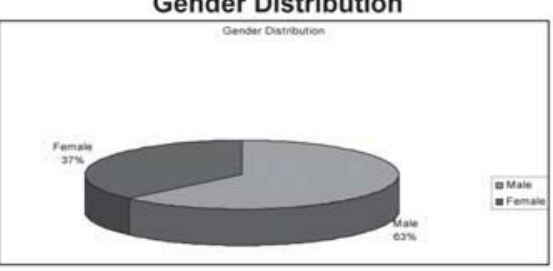

Journal of Independent Studies and Research - MSSE

Volume 8

Number 1

January $2010 \mid 69$ 
The gender of the respondents was as follows;

66 respondents were male, which make up $63 \%$ of the sample and 39 respondents were female, which make up $37 \%$ of the respondents.

The education range of the respondents was divided into 5 categories. 3 respondents or $3 \%$ of the respondents coming in this range. Higher secondary, 15 respondents $(14 \%)$ of the total respondents came in this education range. Graduate or above: The maximum number of respondents were from this category, that is, 88 of the respondents that made up $82 \%$ of the total selected respondents came in this education range.

Figure -3

Education Distribution

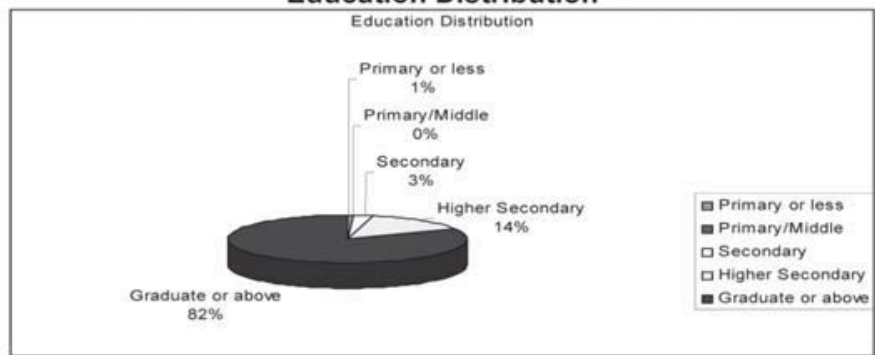

\subsection{Descriptive Analysis}

This section of the analysis looks at the descriptive variables measured in the study. Their mean and standard deviations are presented below with their analysis.

\section{Calculation for Mean and Standard Deviations}

Table - 1

Mean Breakup Channel wise

\begin{tabular}{|l|l|l|l|l|l|}
\hline & Variables & GEO & Express & ARY & Aaj \\
\hline \multirow{5}{*}{ Brand Equity } & Brand Awareness & 4.93 & 4.76 & 4.68 & 4.46 \\
\cline { 2 - 6 } & Brand Knowledge & 4.77 & 4.46 & 4.27 & 3.95 \\
\cline { 2 - 6 } & Perceived Quality & 3.88 & 3.64 & 3.35 & 3.16 \\
\cline { 2 - 6 } & Usability & 3.84 & 3.80 & 3.31 & 3.04 \\
\cline { 2 - 6 } & Loyalty & 3.49 & 3.10 & 2.61 & 2.52 \\
\hline \multirow{5}{*}{ Brand Credibility } & Fairness & 2.85 & 3.50 & 3.07 & 3.02 \\
\cline { 2 - 6 } & Biasness & 2.59 & 3.43 & 3.07 & 3.06 \\
\cline { 2 - 6 } & Completeness & 3.45 & 3.56 & 3.38 & 3.23 \\
\cline { 2 - 6 } & Accuracy & 3.36 & 3.44 & 3.26 & 3.22 \\
\cline { 2 - 6 } & Trust & 3.28 & 3.41 & 2.99 & 2.88 \\
\hline
\end{tabular}

The above table shows that Geo News ranks highest on a scale of 1 to 5 (where these scales are representing as 1-Strongly Disagree 2-Tend to Disagree 3-Neither Agree nor Disagree 4-Tend to Agree and 5-Strongly Agree) in the Brand Awareness, Brand Knowledge, Perceived Quality, Usability and Loyalty. Express news is considered the most fair, bias free, complete, accurate and trustworthy channel. 
The brand awareness of all news channels is found to be very high. The brand knowledge of Aaj TV is lowest at 3.95. The perceived quality of all the four channels on an average is not very high and just above neutral. The usability of the news content of these channels varies from near agreement to neutral attitude. ARY Oneworld and Aaj TV do not have a high level of loyalty and on an average the respondents tend not to watch these two as compared to Geo and Express which enjoy positive loyalty and viewership attitude.

In the matter of fairness with all parties concerned with a news issue, Geo ranks lowest being the most unfair and the most biased news channel in the group. Comparatively Express news is the most unbiased and fair among the selected. In the matter of completeness, that is, telling the whole story Express also ranks highest on average at 3.56 followed by Geo, ARY and Aaj. Express news also ranked the most accurate news provider among the four with an average ranking of 3.44. Finally, Express also ranks first in being the most trusted news channel among the four, followed by Geo, ARY and Aaj TV.

Table - 2

Overall Mean Brand Equity and Mean Brand Credibility

\begin{tabular}{|c|c|c|c|c|c|c|c|c|c|}
\hline & \multicolumn{2}{|c}{ GEO } & \multicolumn{2}{c|}{ Express } & \multicolumn{2}{c|}{ ARY } & \multicolumn{2}{c|}{ Aaj } & Combined \\
\hline & Mean & SD & Mean & SD & Mean & SD & Mean & SD & Mean \\
\hline $\begin{array}{c}\text { Brand } \\
\text { Equity }\end{array}$ & 4.18 & 0.75 & 3.95 & 0.62 & 3.64 & 0.55 & 3.43 & 0.72 & 3.8 \\
\hline $\begin{array}{c}\text { Brand } \\
\text { Credibility }\end{array}$ & 3.10 & 1.14 & 3.47 & 0.87 & 3.15 & 0.65 & 3.08 & 0.71 & 3.2 \\
\hline
\end{tabular}

The above table gives us the overall mean value and standard deviation value of Brand Equity and Brand Credibility of the selected four news channels plus a combined mean value as well. It shows us that that overall GEO News has the highest brand equity in the consumers mind but Express news has the highest brand credibility ranking by mean value among the respondents.

\subsubsection{Geo News Channel}

The combined relationships of the independent variables such as fairness, completeness, accuracy, trust and biasness were tested through multiple estimating regressions equation as presented below:

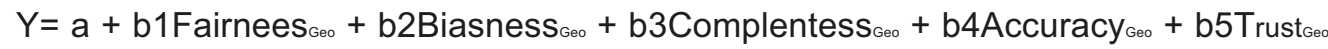
Summarized multiple regression results are presented below:

Table -3

Multiple Regressions (Geo News)

\begin{tabular}{||l|r||}
\hline Regression Statistics & \\
\hline Multiple R & 0.76 \\
\hline R Square & 0.58 \\
\hline Adjusted R Square & 0.56 \\
\hline Standard Error & 0.42 \\
\hline Observations & 105.00 \\
\hline
\end{tabular}


Table -4

ANOVA (Geo News)

\begin{tabular}{||c|c|c|c|c|c||}
\hline & df & SS & MS & F & $\begin{array}{c}\text { Significance } \\
\text { F }\end{array}$ \\
\hline Regression & 5.00 & 23.47 & 4.69 & 27.14 & 0.00 \\
\hline Residual & 99.00 & 17.13 & 0.17 & & \\
\hline Total & 104.00 & 40.60 & & & \\
\hline
\end{tabular}

Table -5

Coefficient (Geo News)

\begin{tabular}{||c|c|c|c|c|c|c||}
\hline \hline & Coef's & $\begin{array}{c}\text { Standard } \\
-\end{array}$ & $t$ Stat & $P$-value & Lower 95\% & Upper 95\% \\
\hline Intercept & 3.02 & 0.12 & 24.18 & 0.00 & 2.77 & 3.27 \\
\hline Fairness & $(0.09)$ & 0.06 & $(1.63)$ & 0.11 & $(0.21)$ & 0.02 \\
\hline Bias & 0.02 & 0.05 & 0.47 & 0.64 & $(0.08)$ & 0.12 \\
\hline Completeness & 0.05 & 0.06 & 0.82 & 0.41 & $(0.07)$ & 0.16 \\
\hline Accuracy & 0.06 & 0.07 & 0.86 & 0.39 & $(0.08)$ & 0.19 \\
\hline Trust & 0.31 & 0.07 & 4.68 & 0.00 & 0.18 & 0.44 \\
\hline
\end{tabular}

The alternate hypothesis that at least one of the independent variables will have the relationship with the dependent variable "Brand equity" is accepted. The ANOVA Table shows that the $F<0$, meaning it is significant. The $R 2$ is 0.58 , which indicates that the combined effect of the independent variables that are completeness, fairness, accuracy, biasness and trust will cause the dependent variable, brand equity of that news channel to move by $58 \%$, which is an indication of a strong relationship. The $P$ value of trust is less than 0.05 , which indicates that the variable trust is relevant to the model, that is, it is stronger predictor of brand equity.

\subsubsection{Express News Channel}

The combined relationships of the independent variables such as fairness, completeness, accuracy, trust and biasness were tested through multiple estimating regressions equation as presented below:

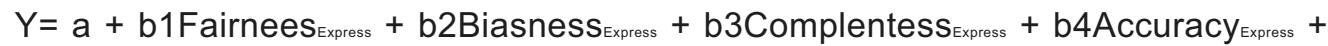
b5Trust Express

Summarized multiple regression results are presented below:

Table -6

Multiple Regression (Express News)

\begin{tabular}{||l|c||}
\hline \hline Regression Statistics & \\
\hline Multiple R & 0.75 \\
\hline R Square & 0.56 \\
\hline Adjusted R Square & 0.53 \\
\hline Standard Error & 0.51 \\
\hline Observations & 105.00 \\
\hline
\end{tabular}


Table -7

ANOVA (Express News)

\begin{tabular}{|c|c|c|c|c|c||}
\hline & $d f$ & SS & MS & $F$ & $\begin{array}{c}\text { Significance } \\
F\end{array}$ \\
\hline Regression & 5.00 & 32.81 & 6.56 & 24.88 & 0.00 \\
\hline Residual & 99.00 & 26.11 & 0.26 & & \\
\hline Total & 104.00 & 58.92 & & & \\
\hline
\end{tabular}

Table - 8

Coefficient (Express News)

\begin{tabular}{|c|c|c|c|c|c|c||}
\hline \hline & Coef's & $\begin{array}{c}\text { Standard } \\
\text { Error }\end{array}$ & $t$ Stat & P-value & $\begin{array}{c}\text { Lower } \\
95 \%\end{array}$ & $\begin{array}{c}\text { Upper } \\
95 \%\end{array}$ \\
\hline Intercept & 1.90 & 0.21 & 8.96 & 0.00 & 1.48 & 2.32 \\
\hline Fairness & 0.21 & 0.09 & 2.32 & 0.02 & 0.03 & 0.39 \\
\hline Bias & $(0.10)$ & 0.08 & $(1.23)$ & 0.22 & $(0.25)$ & 0.06 \\
\hline Completenes & 0.18 & 0.10 & 1.76 & 0.08 & $(0.02)$ & 0.38 \\
\hline Accuracy & 0.07 & 0.12 & 0.56 & 0.58 & $(0.17)$ & 0.31 \\
\hline Trust & 0.23 & 0.09 & 2.47 & 0.02 & 0.04 & 0.41 \\
\hline
\end{tabular}

The ANOVA Table shows that the $F<0$, meaning it is significant. The $R 2$ is 0.56 , which indicates that the combined effect of the will cause the dependent variable, brand equity of that news channel to move by $56 \%$, which is an indication of a strong relationship. The $P$ values of "fairness" and "trust" are less than 0.05 , which indicates that the variables fairness and trust are relevant to the model, that is, they are a stronger predictor of brand equity of Express news.

\subsubsection{ARY Oneworld News Channel}

The combined relationships of the independent variables such as fairness, completeness, accuracy, trust and biasness were tested through multiple estimating regressions equation as presented below:

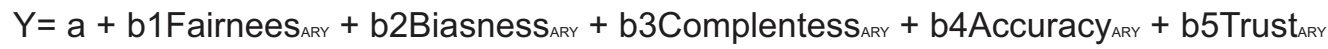
Summarized multiple regression results are presented below:

Table -9

Multiple Regressions (ARY Oneworld)

\begin{tabular}{||l|c||}
\hline Regression Statistics & \\
\hline Multiple R & 0.63 \\
\hline R Square & 0.40 \\
\hline Adjusted R Square & 0.37 \\
\hline Standard Error & 0.44 \\
\hline Observations & 105.00 \\
\hline
\end{tabular}


Table -10

ANOVA (ARY Oneworld)

\begin{tabular}{||c|c|c|c|c|c||}
\hline & $d f$ & SS & MS & $F$ & $\begin{array}{c}\text { Significance } \\
F\end{array}$ \\
\hline Regression & 5.00 & 12.45 & 2.49 & 13.09 & 0.00 \\
\hline Residual & 99.00 & 18.83 & 0.19 & & \\
\hline Total & 104.00 & 31.28 & & & \\
\hline
\end{tabular}

Table -11

Coefficient (ARY Oneworld)

\begin{tabular}{|c|c|c|c|c|c|c||}
\hline & Coef's & Standard & $t$ Stat & $P$-value & Lower 95\% & Upper 95\% \\
\hline Intercept & 2.06 & 0.22 & 9.42 & 0.00 & 1.62 & 2.49 \\
\hline Fairness & 0.11 & 0.07 & 1.47 & 0.15 & $(0.04)$ & 0.26 \\
\hline Bias & 0.09 & 0.06 & 1.47 & 0.14 & $(0.03)$ & 0.21 \\
\hline Completeness s & 0.07 & 0.08 & 0.78 & 0.43 & $(0.10)$ & 0.23 \\
\hline Accuracy & 0.03 & 0.10 & 0.27 & 0.79 & $(0.17)$ & 0.22 \\
\hline Trust & 0.22 & 0.07 & 3.03 & 0.00 & 0.08 & 0.37 \\
\hline \hline
\end{tabular}

The ANOVA Table shows that the $\mathrm{F}<0$, meaning it is significant. The $\mathrm{R} 2$ is 0.4 , which indicates that the combined effect of the independent variables that are completeness, fairness, accuracy, biasness and trust will cause the dependent variable, brand equity of that news channel to move by $40 \%$, which is an indication of a moderate relationship. The $P$ value "trust" is less than 0.05 , which indicates that the variable trust is relevant to the model, that is, it is a stronger predictor of brand equity for ARY Oneworld news channel.

\subsubsection{Aaj TV Channel}

The combined relationships of the independent variables such as fairness, completeness, accuracy, trust and biasness were tested through multiple estimating regressions equation as presented below:

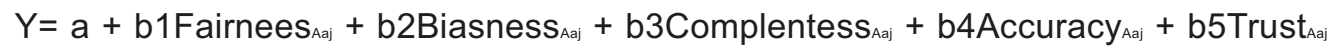
Summarized multiple regression results are presented below:

Table - 12

Multiple Regression (Aaj TV)

\begin{tabular}{||l|c||}
\hline Regression Statistics & \\
\hline Multiple R & 0.63 \\
\hline R Square & 0.40 \\
\hline Adjusted R Square & 0.37 \\
\hline Standard Error & 0.57 \\
\hline Observations & 105.00 \\
\hline
\end{tabular}


Table -13

ANOVA (Aaj TV)

\begin{tabular}{||c|c|c|c|c|c||}
\hline & $d f$ & SS & MS & $F$ & $\begin{array}{c}\text { Significance } \\
F\end{array}$ \\
\hline Regression & 5.00 & 21.41 & 4.28 & 13.26 & 0.00 \\
\hline Residual & 99.00 & 31.96 & 0.32 & & \\
\hline Total & 104.00 & 53.37 & & & \\
\hline
\end{tabular}

Table -14

Coefficient (Aaj TV)

\begin{tabular}{||c|c|c|c|c|c|c||}
\hline \hline & Coef's & $\begin{array}{c}\text { Standard } \\
5\end{array}$ & $t$ Stat & P-value & Lower 95\% & Upper 95\% \\
\hline Intercept & 1.96 & 0.26 & 7.46 & 0.00 & 1.44 & 2.48 \\
\hline Fairness & $(0.01)$ & 0.10 & $(0.11)$ & 0.91 & $(0.20)$ & 0.18 \\
\hline Bias & $(0.01)$ & 0.10 & $(0.12)$ & 0.90 & $(0.21)$ & 0.18 \\
\hline Completeness & 0.20 & 0.11 & 1.85 & 0.07 & $(0.01)$ & 0.42 \\
\hline Accuracy & $(0.14)$ & 0.13 & $(1.09)$ & 0.28 & $(0.40)$ & 0.12 \\
\hline Trust & 0.46 & 0.09 & 4.98 & 0.00 & 0.28 & 0.65 \\
\hline
\end{tabular}

The alternate hypothesis that at least one of the independent variables will have the relationship with the dependent variable "Brand equity" is accepted.

The ANOVA Table shows that the $F<0$, meaning it is significant. The $R 2$ is 0.4 , which indicates that the combined effect of the independent variables will cause the dependent variable, brand equity of that news channel to move by $40 \%$, which is an indication of a moderate relationship. The $P$ value "trust" is less than 0.05 , which indicates that the variable trust is relevant to the model, that is, it is a stronger predictor of brand equity for Aaj TV news channel.

Table - 15

Adjusted R squared Values (All Channels)

\begin{tabular}{||c|c|}
\hline & Adjusted $R$ squared Values \\
\hline GEO NEWS & 0.56 \\
\hline EXPRESS NEWS & 0.53 \\
\hline ARY ONEWORLD & 0.37 \\
\hline AAJ TV & 0.37 \\
\hline
\end{tabular}

\section{Results and Findings}

The analysis and results of this study have brought forth the following key findings Respondents had the highest level of brand awareness, brand knowledge, highest 
perceived quality, maximum usability and strongest loyalty with Geo news and lowest for Aaj TV.

The hypothesis testing validated the adapted model and the usage of the indicators to measure the variables. The alternate hypothesis that at least one of the independent variables will have the relationship with the dependent variable "Brand equity" was accepted with Strong $R$ squared values for Geo News, Express News and moderate $R$ squared value in the case of ARY Oneworld and Aaj TV. After individual channel analysis and hypothesis testing, it was found that out of the 5 independent variables that constituted "Brand Credibility", the variable "Trust" was the strongest predictor of the dependant variable "Brand Equity" in the case for each channel On analyzing average values of the Brand Credibility indicators, it was revealed that GEO News was ranked as the most unfair and biased news channel among the four channels while Express news was the most fair and unbiased. Measuring the Brand Credibility indicators also revealed that Express News was ranked on average among the four channels selected in this study. Express News showed the highest brand credibility by being the most trusted, accurate and complete news provider, fair and unbiased news channel among the four channels

The overall Brand awareness of all the four channels was high compared to their overall neutral/low perceived quality of reporting on average. Geo News enjoys the highest overall brand equity in the respondents' minds. Express News enjoys the highest overall brand credibility in the respondents' view

\section{Conclusion}

When choosing a topic for this study many topics came to mind but after a brief literature survey it was seen that there was little research done on the private news channels and their brand credibility among the viewers in Pakistan.

The research aimed to study the audiences' perception about the brand credibility of these channels and whether this had any relationship or association with the brand equity of that channel. This research initially was planned to target the entire city of Karachi but with limited resources was confined to North Nazimabad town. The data collected through a two section questionnaire, measured the respondents views on 10 variables related to brand equity and brand credibility. The hypothesis was tested for each channel through regression analysis, multiple regressions, ANOVA and coefficient analysis.

The initial secondary data suggested that Geo News would be the most credible news channel in the selected group which has been found not to be true from the study results. But the respondents still showed maximum loyalty to this channel. A unique phenomenon which can be studied further. The findings of the study helped to validate the adapted model for this research and revealed to us that in case of private news channels, trust is the strongest predictor of brand equity of those news channels. 


\section{Recommendations}

In light of the above findings, some practical recommendations can be made; The private news media industry is lacking in the impeccably high quality of news reporting that is the core of any journalistic enterprise and needs to invest resources into improving the quality of news that is being reported as a whole. Aaj TV should initiate a public relations campaign with an integrated marketing campaign to improve its brand credibility and brand equity among the viewers. Similarly Geo News should strive towards building its brand credibility to match its brand equity through an aggressive and extensive public relations campaign to boost its credibility as a fair and unbiased news channel.

Express News should focus on an integrated and creative marketing campaign to build upon its high brand credibility to concurrently increase its brand equity. ARY Oneworld and Aaj TV need to improve upon their brand credibility which will also help to improve their brand loyalty by gaining the top of mind brand recall in the customers' mind which is currently strongly held by Geo News.

\section{Future Areas of Study}

For future areas of research, we suggest that this research should be expanded in two areas; Firstly additional research should be conducted by including a broader number of news channels to validate the results of this study. Secondly the study should be expanded geographically to include a more diverse population base from the entire country to better generalize the results of this study.

A comparative study can also be conducted using state owned channels and private channels and the subsequent findings used to further validate the relationship between brand credibility and brand equity in the news media industry.

Another suggested area of study would be to validate these results for other media types besides cable television like internet news or print newspapers in Pakistan. 


\section{References}

Aaj TV (2009). Available at: http://www.aaj.tv/ (Accessed on 18 February 2009)

Aaker, Alexander L. \& Biel (1993), Brand Equity \& Advertising: Advertising's Role in Building Strong Brands, Lawrence Erlbaum Associates, ISBN 0805812849

Aaker, DA (1991), Managing Brand Equity: Capitalizing on the Value of A Brand Name, Free Press, ISBN 0029001013

American Marketing Association (2009). Available at: http://www.marketingpower.com/ (Accessed: 28 February 2009)

Andersen and Gray (2007), Battleground: The Media, Greenwood Publishing Group, ISBN 0313341672

ARY Oneworld (2009). Available at:http://www.thearynews.com/ (Accessed 18 February 2009)

Banerjee, Logan et al (2008), Asian Communication Handbook 2008, AMIC, ISBN 9814136107

Belch, M., Belch, G. (2004), Advertising and Promotion: An Integrated Marketing Communications Perspective, Tata McGraw-Hill, Edition 6, ISBN 0070581940

Blackshaw, P. (2008), Satisfied Customers Tell Three Friends, Angry Customers Tell 3,000: Running a Business in Today's Consumer-Driven World, Doubleday, ISBN 9780385522724

Express News (2009). Available at: http://www.expressnews.tv/ (Accessed: 18 February 2009)

Gaziano, C., Mcgrath, K. (1986), 'Measuring the Concept of Credibility', Journalism Quarterly, 63

Geo TV (2009). Available at: http://geo.tv/ (Accessed: 16 February 2009)

Hachten (2001), The Troubles of Journalism: A Critical Look at What's Right and Wrong with the Press, Lawrence Erlbaum Associates, Edition 2, ISBN 9780805838176

Keller, K.L, (1993), 'Conceptualizing, Measuring, and Managing Customer-Based Brand Equity', Journal of Marketing, 57, p 1-22

Medialogic Pakistan (Pvt) Ltd. (2009). Available at: http://medialogic.com.pk/tam/index.html (Accessed: 12 March 2009) 
Meyer, P. (1988), 'Defining and Measuring Credibility of Newspapers: Developing an Index', Journalism Quarterly, 65, p 567-574

Mindich (2000), Just the Facts: How "Objectivity" Came to Define American Journalism, NYU Press, 9780814756140

Oyedeji, T. (2006), 'The Relationship Between the Media Channel Credibility and Brand Equity of Media Outlets', International Communication Association Conference (ICA), Germany, June 2006

Pakistan Electronic Media Regulatory Authority (2009). Available at: http://www.pemra.gov.pk/ (Accessed: 18 January 2009)

Rimmer and Weaver (1987), 'Different Questions, Different Answers? Media Use and Media Credibility', Journalism Quarterly, Edition 64, no. 1, p28-36.

Streissguth (2006), Media Bias, Marshall Cavendish, ISBN 9780761422969

West, M.D. (1994), Validating a Scale for the Measurement of Credibility: A Covariance Structure Modeling Approach, Journalism Quarterly, 71, p 158-168.

Yoo, B.C. and Donthu, N. (2001), 'Developing and Validating a Multidimensional Consumer-Based Brand Equity Scale', Journal of Business Research, 52, p 1-15 